\title{
STUDY ON VARYING SALT LEVEL AND STORAGE TIME ON PHYSICO-CHEMICAL AND SENSORY QUALITY OF BEEF NUGGET
}

\author{
M. A. K. Talukder, M. A. Hashem*, S. M. E. Rahman, M. S. Islam, \\ M. M. Hossain, M. S. Ali ${ }^{1}$, M. A. K. Azad and R. Luna \\ Department of Animal Science, Bangladesh Agricultural University \\ Mymensigh-2202, Bangladesh
}

\begin{abstract}
The experiment was conducted to find out the effect of salt and storage temperature on the physico-chemical properties of beef nugget. For this purpose nugget samples were divided into two parts; one is called fresh nugget and another is preserved nugget at different temperatures. Then the fresh samples as well as the preserved samples were divided into four subdivisions. Then these are treated with different salt levels $(0,1.5,3$ and $5 \%$ salt level). The preserved samples were stored at $4^{\circ} \mathrm{C}$ and $-20^{\circ} \mathrm{C}$. Samples preserved at $4^{\circ} \mathrm{C}$ were stored in the refrigerator for 21 days and were analyzed on $7^{\text {th }}$ day, $14^{\text {th }}$ day and $21^{\text {th }}$ day and samples preserved at $-20^{\circ} \mathrm{C}$ were stored in the refrigerator for 60 days and were analyzed on $15^{\text {th }}$ day, $30^{\text {th }}$ day, $45^{\text {th }}$ day and $60^{\text {th }}$ day of preservation. Dry matter and Ash content of all the samples increased significantly $(\mathrm{P}<0.01)$ with the advancement of storage time and salt level. CP\% of fresh samples was 22.31, 20.55, 20.13 and 20.55 at $0,1.5,3$ and $5 \%$ salt concentration. CP, DM, Ash and Fat also varied among the samples significantly $(\mathrm{P}<0.01)$. Highly significant difference is observed in preserved samples than in fresh samples at different salt levels. Fresh nugget treated with $1.5 \%$ salt found to be more acceptable in terms of sensory evaluation. So we recommend fresh nugget to be best for consumption.
\end{abstract}

Key Words: Beef nugget, Salt, Forzen nugget, Refrizerated nugget

\section{INTRODUCTION}

Livestock is one of the recognized integral components of Agricultural production process. It plays potential role in the national economy being a vital component of Agriculture. The livestock population in Bangladesh consists of 22.90 million cattle, 1.26 million buffalo, 21.56 million goat and 2.78 million sheep (DLS, 2009). It is noted that 75 per cent cattle population of the world is in the developing countries but its contribution is only 34 per cent to the beef production (Rahman, 1992). Animal protein is the most essential element for human physiology. Meat and meat products such as nugget play an important role in nutrition as a contributor of high quality protein. Nugget is a meat product that is popular worldwide. Though this product demand is highly concentrated in western but it also getting more

\footnotetext{
1Department of Poultry Science, Bangladesh Agricultural University, Mymensigh-2202, Bangladesh *Corresponding author (Email: hashem_mdabul@yahoo.com)
} 
demand in Asia. Nugget is a popular meat product as it requires less time to prepare and nutritionally more acceptable than other food product. Studies in meat consumption in last decade have shown the health and nutritional value of a product is a major factor in consumer preference (Angulo and Gil, 2007 and Fonseca and Salay, 2008). Cardiovascular disease (CVD) accounts for $30 \%$ of all deaths across the world (World Health Organization, 2009). Hypertension a term which describes high blood pressure has high a global prevalence. Many studies have shown a link between a high intake of dietary sodium and hypertension (Dahl, 1972 and Law et al., 1991a, 1991b). The main source of sodium (75\% of total dietary intake) comes from processed food. Consumers are becoming more health conscious and this is leading to a growing preference for healthier, more nutritious and more functional food products. For beef nugget, much attention has focused on its chemical composition and higher shelf-life. Processed meats can also contain high levels of animal fat, high levels of fat have been associated with increased risk of promoting obesity, diabetes and also cancers especially colon cancers (Aggett et al., 2005). Salt is a vital ingredient in processed meat as it has numerous technological benefits such as preservation, taste enhancement and water binding (Durack et al., 2008). Water holding capacity is defined as the ability of a food to enclose liquid within a three dimensional structure (Chantrapornchai and McClements, 2002). Salt is able to increase the water holding capacity of a meat product by extracting myofibrillar proteins which associate into a gel when heated (Foegeding and Lanier, 1987).

However, it is still important to obtain an acceptable limit at which salt can be reduced from processed meat products without negatively impacting functionality, product quality or adversely affect sensorial acceptability, so as to enhance the health status of processed meats. Work carried out by Tobin et al. (2012a) and Tobin et al. (2012b) have shown salt reduction can be successfully reduced in processed meat products such as burgers and frankfurters.

The aim of preservation is not only to retard the food spoilage but also to control undesirable changes of wholesomeness, nutritive value and growth of microorganisms (Fennema, 1975). Freezing is the only known method by which nugget can be preserved in a condition similar to their normal state. Freezing at different temperature affect the nugget quality.

The present research work was conducted with a view to identify the acceptable salt level of nugget, the quality of nugget and to find the effect of preservation temperature on the chemical composition of nugget.

\section{MATERIALS AND METHODS}

\section{Collection of meat}

Fresh samples were collected from cattle slaughtered in Sheep and Goat Farm, Department of Animal Science, Bangladesh Agricultural University, Mymensingh. Chemical analysis was carried out in the Animal Science Laboratory, Department of Animal Science, BAU, Mymensingh. 


\section{Sample preparation}

All visible fat and connective tissue were trimmed off as far as possible with the help of knife and the sample was cut into small pieces. Beef was grinded with the help of meat grinder, then mixed with some spices i.e. chili powder, turmeric powder etc. The meat was aliquot into 4 parts. Each part was mixed with salt at 0,1.5\%,3\%,5\% respectively according to weight basis. Meat from each mixture was taken and wrapped with small square pieces of plastic as a casing. Both end of bag were tied with thread for not entering water and were then placed in to boiling water for cooking. These procedure were made for three times to prepare sample to analyze the first one as fresh basis and the other two were kept in two different freezes at $4{ }^{\circ} \mathrm{C}$ and $-20^{\circ} \mathrm{C}$, respectively for further analysis in various days interval of preservation; it was named the refrigerated sausage. The second portion (freezing temperature $-20^{\circ} \mathrm{C}$ ) of the sausage was named the frozen sausage. Then the samples were packaged in polyethylene bags separately and was kept into the freeze.

\section{Defrosting process}

After storing 7, 14 and 21 and for 15, 30, 45 and 60 days, the samples were defrosted by air, water and microwave oven to prepare for chemical analysis.

\section{Proximate composition}

Proximate composition such as Dry Matter (DM), Ether Extract (EE), Crude Protein (CP) and Ash were measured according to the methods (AOAC, 1995). All determination was done in triplicate and the mean value was reported.

\section{pH measurement}

$\mathrm{pH}$ value of meat was measured using $\mathrm{pH}$ meter from meat homogenate. The homogenate was prepared by blending $2 \mathrm{~g}$ of meat with $10 \mathrm{ml}$ distilled water.

\section{Statistical analysis}

Data were analyzed statistically using the analysis of variance technique in a computer using SAS statistical computer package programmed in accordance with the principle of Completely Randomized Design (CRD). Duncan's Multiple Range Test was done to compare variations between treatments where ANOVA showed significant differences.

\section{RESULTS AND DISCUSSION}

\section{Proximate Composition}

\section{Dry matter}

Dry matter (DM) content of sausage at different salt concentration, storage temperature and days are presented in Table 1 . DM of fresh nugget of $0 \%$ salt was $30.59 \%$, refrigerated nugget and frozen nugget of $0 \%$ salt at 21 days and 60 days were $32.61 \%$ and 31.64\%, respectively. DM of fresh nugget of $1.5 \%$ salt was $30.48 \%$ and refrigerated and frozen nugget of $1.5 \%$ salt sample at 21 and 60 days were $32.60 \%$ and $31.17 \%$, respectively. DM of fresh beef nugget of $3.0 \%$ salt was $30.67 \%$ and refrigerated and frozen nugget of $3.0 \%$ salt at 21 and 60 days were $32.45 \%$ and $32.09 \%$, respectively. DM of fresh nugget of $5.0 \%$ salt was 
$30.86 \%$ and refrigerated and frozen nugget of $5.0 \%$ salt at 21 and 60 days were $32.46 \%$ and $33.24 \%$, respectively. There were little changes of DM content during storage time. DM content increased with the increase of storage time and salt concentration in all samples. The loss of moisture probably associated with the increase of DM. This result is mached with the findings of Konieczny et al. (2007) and they reported that DM content increased during refrigerated storage. DM increased for the loss of moisture of beef nugget with advance of storage time during freezing. Our result is little bit lower than those of findings of Lukman et al. (2009) where the authors found that the the dry matter ranged from $34.71 \%$ to $40.83 \%$ in commercial chicken nugget. Because this variation might be due to beef intead of using chicken meat in commercial chicken nugget.

Table 1. Proximate composition of nugget

\begin{tabular}{|c|c|c|c|c|c|c|c|c|c|}
\hline \multirow[t]{2}{*}{ Treatment } & \multirow[t]{2}{*}{ Parameters } & \multirow[t]{2}{*}{$\begin{array}{c}\text { Fresh } \\
\text { sample }\end{array}$} & \multicolumn{3}{|c|}{$\begin{array}{l}\text { Refrigerated } \\
\text { sample }\end{array}$} & \multicolumn{4}{|c|}{ Frozen sample } \\
\hline & & & 7 Days & 14 Days & 21 Days & 15 Days & 30 Days & 45 Days & 60 Days \\
\hline \multirow[t]{6}{*}{$\mathrm{T}_{1}$} & DM\% & 30.59 & 30.65 & 31.02 & 32.61 & 31.09 & 31.29 & 31.14 & 31.64 \\
\hline & Ash \% & 1.17 & 1.13 & 1.08 & 1.06 & 1.26 & 1.28 & 1.27 & 1.32 \\
\hline & $\mathrm{CP} \%$ & 22.31 & 21.63 & 21.48 & 21.44 & 20.22 & 20.45 & 19.73 & 19.33 \\
\hline & Fat $\%$ & 7.85 & 7.64 & 7.74 & 7.75 & 7.23 & 7.22 & 7.20 & 6.90 \\
\hline & $\mathrm{pH}$ & 5.69 & 5.71 & 5.68 & 5.75 & 5.68 & 4.74 & 4.70 & 4.25 \\
\hline & CL\% & 26.67 & 23.63 & 22.02 & 21.63 & 30.19 & 30.17 & 30.16 & 31.16 \\
\hline \multirow[t]{6}{*}{$\mathrm{T}_{2}$} & DM\% & 30.48 & 30.66 & 31.42 & 32.60 & 30.94 & 31.02 & 30.43 & 31.17 \\
\hline & Ash \% & 1.19 & 1.17 & 1.11 & 1.07 & 1.24 & 1.21 & 1.25 & 1.30 \\
\hline & $\mathrm{CP} \%$ & 20.55 & 21.30 & 20.24 & 20.47 & 20.90 & 20.71 & 20.55 & 20.15 \\
\hline & Fat $\%$ & 7.53 & 7.54 & 7.48 & 7.46 & 7.24 & 7.13 & 7.27 & 6.97 \\
\hline & $\mathrm{pH}$ & 4.79 & 4.76 & 4.55 & 4.51 & 4.98 & 4.93 & 4.97 & 5.19 \\
\hline & CL\% & 28.19 & 26.35 & 26.53 & 24.35 & 28.35 & 30.03 & 30.06 & 31.06 \\
\hline \multirow[t]{6}{*}{$\mathrm{T}_{3}$} & DM\% & 30.67 & 30.68 & 30.99 & 32.45 & 31.70 & 31.27 & 31.59 & 32.09 \\
\hline & Ash \% & 1.20 & 1.17 & 1.06 & 1.07 & 1.18 & 1.19 & 1.13 & 1.15 \\
\hline & $\mathrm{CP} \%$ & 20.13 & 21.28 & 23.33 & 20.37 & 19.84 & 20.22 & 22.93 & 22.53 \\
\hline & Fat $\%$ & 7.52 & 7.43 & 7.49 & 7.47 & 7.18 & 7.19 & 7.14 & 6.84 \\
\hline & $\mathrm{pH}$ & 4.81 & 4.75 & 5.25 & 4.98 & 4.76 & 4.89 & 5.47 & 5.30 \\
\hline & CL\% & 28.16 & 28.07 & 27.64 & 25.71 & 28.53 & 28.49 & 29.64 & 30.64 \\
\hline \multirow[t]{6}{*}{$\mathrm{T}_{4}$} & DM\% & 30.86 & 30.49 & 31.54 & 32.46 & 32.87 & 32.73 & 32.74 & 33.24 \\
\hline & Ash\% & 1.21 & 1.18 & 1.11 & 1.10 & 1.14 & 1.17 & 1.14 & 1.19 \\
\hline & $\mathrm{CP} \%$ & 20.55 & 21.11 & 20.62 & 20.45 & 20.07 & 20.05 & 19.94 & 19.51 \\
\hline & Fat $\%$ & 7.51 & 7.47 & 7.44 & 7.39 & 7.09 & 7.17 & 7.09 & 6.79 \\
\hline & $\mathrm{pH}$ & 4.86 & 4.71 & 4.71 & 4.65 & 4.72 & 4.87 & 5.19 & 5.18 \\
\hline & CL\% & 28.17 & 28.01 & 26.49 & 24.12 & 26.35 & 26.12 & 27.71 & 28.71 \\
\hline
\end{tabular}

$\mathrm{T}_{1}=0 \%$ salt; $\mathrm{T}_{2}=1.5 \%$ salt concentration; $\mathrm{T}_{3}=3 \%$ salt concentration and $\mathrm{T}_{4}=5 \%$ salt concentration; $\mathrm{CL}$ = Cooking loss 


\section{Ash}

Ash was also analyzed up to the end of the storage period of 60 days and the results are presented in Table 1. Ash of fresh nugget of $0 \%$ salt was $1.17 \%$, refrigerated and frozen nugget of $0 \%$ salt at 21 days and 60 days were $1.06 \%$ and $1.32 \%$, respectively. Ash of fresh nugget of $1.5 \%$ salt was $1.19 \%$ and refrigerated and frozen nugget of $1.5 \%$ salt at 21 and 60 days were $1.07 \%$ and $1.30 \%$, respectively. Ash of fresh beef nugget of $3.0 \%$ salt sample was $1.20 \%$ and refrigerated and frozen nugget of $3.0 \%$ salt at 21 and 60 days were $1.07 \%$ and $1.15 \%$, respectively Ash of fresh nugget of $5.0 \%$ salt was $1.21 \%$ and refrigerated and frozennugget of $5.0 \%$ salt at 21 and 60 days were $1.10 \%$ and $1.19 \%$, respectively. Ash value increased with the increase of storage time and salt concentration. Our result is well matched with the findings of Lukman et al. (2009) where the authors found that the ash ranged from $1.20 \%$ to $1.52 \%$ in commercial chicken nugget.

\section{Crude protein}

Crude protein $(\mathrm{CP})$ content was also determined at the end of the storage period of 60 days and the results are presented in Table 1 . CP of fresh nugget of $0 \%$ salt was $22.31 \%$ and refrigerated and frozen nugget of $0 \%$ salt at 21 days and 60 days were $21.44 \%$ and $19.33 \%$, respectively. $\mathrm{CP}$ of fresh nugget of $1.5 \%$ salt was $20.55 \%$ and refrigerated and frozen nugget of $1.5 \%$ salt at 21 and 60 days were $20.47 \%$ and $20.15 \%$, respectively. CP of fresh beef nugget of $3.0 \%$ salt was $20.13 \%$ and refrigerated and frozen nugget of $3.0 \%$ salt at 21 and 60 days were $20.37 \%$ and $22.53 \%$, respectively. CP of fresh nugget of $5.0 \%$ salt was $20.55 \%$ and refrigerated and frozen nugget of $5.0 \%$ salt at 21 and 60 days were $20.45 \%$ and $19.51 \%$, respectively. The $\mathrm{CP}$ content decreased in samples due to storage might be related with loss of sarcoplasmic protein, osmosis and poor water holding capacity. Our result is little bit higher than those of findings of Lukman et al. (2009) where the authors found that the the $\mathrm{CP}$ ranged from $12.52 \%$ to $16.62 \%$ in commercial chicken nugget. Because this variation might be due to beef intead of using chicken meat in commercial chicken nugget.

\section{Fat}

Fat content of samples was also analyzed up to the end of the storage period of 60 days and the results are presented in Table 1. Fat of fresh nugget of $0 \%$ salt was $7.85 \%$ and refrigerated and frozen nugget of $0 \%$ salt at 21 days and 60 days were $7.75 \%$ and $6.90 \%$, respectively. Fat of fresh nugget of $1.5 \%$ salt was $7.53 \%$ and refrigerated and frozen nugget of $1.5 \%$ salt at 21 and 60 days were $7.46 \%$ and $6.97 \%$, respectively. Fat of fresh beef nugget of $3.0 \%$ salt was $7.52 \%$ and refrigerated and frozen nugget of $3.0 \%$ salt at 21 and 60 days were $7.47 \%$ and $6.84 \%$, respectively. Fat of fresh nugget of $5.0 \%$ salt was $7.51 \%$ and refrigerated and frozen nugget of $5.0 \%$ salt at 21 and 60 days were $7.39 \%$ and $6.79 \%$, respectively. Fat of nugget decreased with advanced of storage time, temperature and salt concentration. Our result is lower than those of findings of Lukman et al. (2009) where the authors found that the fat ranged from $18.14 \%$ to $25.00 \%$ in commercial chicken nugget. Because this variation might be due to beef intead of using chicken meat as well as other fatty substances has been added in commercial chicken nugget.

\section{$p H$}

$\mathrm{pH}$ value of samples was also analyzed up to the end of the storage period of 60 days and the results are presented in Table 1. $\mathrm{pH}$ of fresh nugget of $0 \%$ salt was 5.69 , refrigerated and 
frozen nugget of $0 \%$ salt at 21 days and 60 days were 5.75 and 4.25 , respectively. $\mathrm{pH}$ of fresh nugget of $1.5 \%$ salt was 4.79 and refrigerated and frozen nugget of $1.5 \%$ salt at 21 and 60 days were 4.51 and 5.19, respectively. $\mathrm{pH}$ of fresh beef nugget of $3.0 \%$ salt was 4.81 and refrigerated and frozen nugget of $3.0 \%$ salt at 21 and 60 days were 4.98 and 5.30, respectively. $\mathrm{pH}$ of fresh nugget of $5.0 \%$ salt was 4.86 and refrigerated and frozen nugget of $5.0 \%$ salt at 21 and 60 days were 4.56 and 5.18, respectively. $\mathrm{pH}$ value of beef nugget increased with advanced of storage time and decreased with advance of temperature and salt concentration.

\section{Cooking loss}

Cooking loss of samples was also analyzed up to the end of the storage period of 60 days and the results are presented in Table 1. Cooking loss of fresh nugget of $0 \%$ salt was $26.67 \%$ and refrigerated and frozen nugget of $0 \%$ salt at 21 days and 60 days were $21.63 \%$ and $31.16 \%$, respectively. Cooking loss of fresh nugget of $1.5 \%$ salt was $28.19 \%$ and refrigerated and frozen nugget of $1.5 \%$ salt at 21 and 60 days were $24.35 \%$ and $31.06 \%$, respectively. Cooking loss of fresh nugget of $3.0 \%$ salt was $28.16 \%$ and refrigerated and frozen nugget of $3.0 \%$ salt at 21 and 60 days were $25.71 \%$ and $30.64 \%$, respectively. Cooking loss of fresh nugget of $5.0 \%$ salt was $28.17 \%$ and refrigerated and frozen nugget of $5.0 \%$ salt at 21 and 60 days were $24.12 \%$ and $28.71 \%$, respectively. Cooking loss of nugget decreased with advanced of salt concentration but increased with advanced of storage time and temperature.

\section{Sensory evaluation}

Table 2 shows the result of sensory evaluation of beef nugget. Fresh nuggets were analyzed for their color, tenderness, juiciness, flavor, texture, coarseness, hardness, saltiness taste and overall impression by 5 panelists familiar with nugget evaluation. Panelists were selected among teachers. Sensory evaluation was carried out in controlled conditions of light, temperature and humidity. Prior to sample evaluation, all panelists participated in orientation sessions to familiarize with the scale attributes (off-odor, freshness, overall, and so on) of fresh nugget using an intensity scale. Sensory qualities of the samples were evaluated using a 5-point scoring method. Sensory scores were 5 for excellent, 4 for very good, 3 for good, 2 for fair and 1 for poor. All samples were served in the Petri dishes and were returned for further chemical analysis. Sensory evaluation was accomplished at day 0 .

Table 2. Attributes on sensory evaluation of nugget

\begin{tabular}{l|c|c|c|c|c}
\hline Treatments & $\begin{array}{c}\text { Acceptability of } \\
\text { color }\end{array}$ & Juiciness & Flavor & Saltiness Taste & $\begin{array}{c}\text { Overall } \\
\text { impression }\end{array}$ \\
\hline $\mathrm{T}_{1}$ & $3.40^{\mathrm{b}} \pm 0.12$ & $4.60^{\mathrm{a}} \pm 0.12$ & $3.60^{\mathrm{b}} \pm 0.12$ & $0.00 \pm 0.00$ & $0.20^{\mathrm{d}} \pm 0.10$ \\
$\mathrm{~T}_{2}$ & $3.20^{\mathrm{b}} \pm 0.19$ & $4.00^{\mathrm{b}} \pm 0.00$ & $4.80^{\mathrm{a}} \pm 0.10$ & $4.60^{\mathrm{a}} \pm 0.12$ & $4.80^{\mathrm{a}} \pm 0.10$ \\
$\mathrm{~T}_{3}$ & $4.60^{\mathrm{a}} \pm 0.12$ & $3.00^{\mathrm{c}} \pm 0.16$ & $3.80^{\mathrm{b}} \pm 0.10$ & $2.40^{\mathrm{b}} \pm 0.12$ & $3.60^{\mathrm{b}} \pm 0.12$ \\
$\mathrm{~T}_{4}$ & $3.60^{\mathrm{b}} \pm 0.12$ & $2.00^{\mathrm{d}} \pm 0.00$ & $2.00^{\mathrm{c}} \pm 0.00$ & $0.40^{c} \pm 0.12$ & $2.80^{c} \pm 0.10$ \\
\hline
\end{tabular}

$\mathrm{T}_{1}=0 \%$ salt; $\mathrm{T}_{2}=1.5 \%$ salt concentration; $\mathrm{T}_{3}=3 \%$ salt concentration and $\mathrm{T}_{4}=5 \%$ salt concentration. Within same column having mean with different superscripts differ significantly $(\mathrm{P}<0.05)$ 


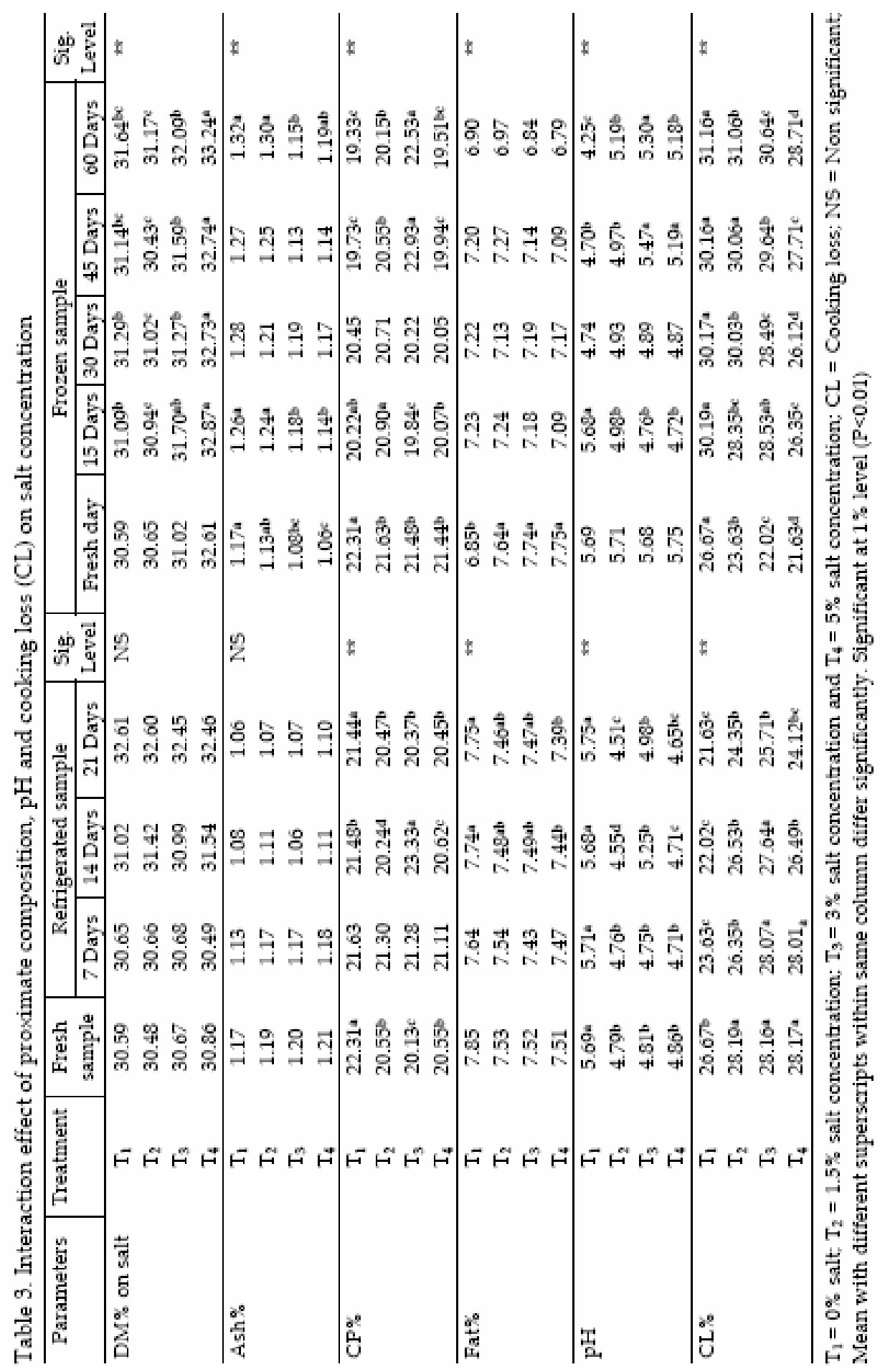


Table 4. Interaction effect of proximate composition, $\mathrm{pH}$ and cooking loss (CL) of fresh and refrigerated nugget on storage time

\begin{tabular}{|c|c|c|c|c|c|c|}
\hline \multirow[t]{2}{*}{ Parameters } & \multirow{2}{*}{$\begin{array}{c}\text { Duration } \\
\text { (days) }\end{array}$} & \multicolumn{4}{|c|}{ Treatment } & \multirow{2}{*}{$\begin{array}{l}\text { Sig. } \\
\text { Level }\end{array}$} \\
\hline & & $\mathrm{T}_{1}$ & $\mathrm{~T}_{2}$ & $\mathrm{~T}_{3}$ & $\mathrm{~T}_{4}$ & \\
\hline \multirow[t]{4}{*}{$\mathrm{DM} \%$} & 0 & 30.59 & $30.48^{c}$ & $30.67 c$ & $30.86^{c}$ & ** \\
\hline & 7 & 30.65 & $30.66^{c}$ & $30.68^{c}$ & $30.49 \mathrm{~d}$ & \\
\hline & 14 & 31.02 & $31.42^{b}$ & $30.99 b$ & $31.54^{b}$ & \\
\hline & 21 & 32.61 & $32.60^{a}$ & $32.45^{\mathrm{a}}$ & $32.46^{\mathrm{a}}$ & \\
\hline \multirow[t]{4}{*}{ Ash\% } & 0 & $1.17 \mathrm{a}$ & $1.19 \mathrm{a}$ & $1.20^{a}$ & 1.21 & $* *$ \\
\hline & 7 & $1.13^{\mathrm{ab}}$ & $1.17 \mathrm{ab}$ & $1.17 \mathrm{~b}$ & 1.18 & \\
\hline & 14 & $1.08 \mathrm{bc}$ & $1.11^{b c}$ & $1.06^{c}$ & 1.11 & \\
\hline & 21 & $1.06^{c}$ & $1.07 \mathrm{c}$ & $1.07 \mathrm{c}$ & 1.10 & \\
\hline \multirow[t]{4}{*}{$\mathrm{CP} \%$} & 0 & $22.31^{a}$ & $20.55^{b}$ & $20.13 d$ & $20.55^{b}$ & $* *$ \\
\hline & 7 & $21.63^{b}$ & $21.30^{a}$ & $21.28^{b}$ & $21.11^{\mathrm{a}}$ & \\
\hline & 14 & $21.48^{b}$ & $20.24^{b}$ & $23.33^{a}$ & $20.62^{b}$ & \\
\hline & 21 & $21.44^{\mathrm{b}}$ & $20.47 \mathrm{~b}$ & $20.37 \mathrm{c}$ & $20.45^{b}$ & \\
\hline \multirow[t]{4}{*}{ Fat $\%$} & 0 & $7.85^{\mathrm{a}}$ & 7.53 & 7.52 & 7.51 & $* *$ \\
\hline & 7 & $7.64^{\mathrm{b}}$ & 7.54 & 7.43 & 7.47 & \\
\hline & 14 & $7.74^{\mathrm{ab}}$ & 7.48 & 7.49 & 7.44 & \\
\hline & 21 & $7.75^{\mathrm{ab}}$ & 7.46 & 7.47 & 7.39 & \\
\hline \multirow[t]{4}{*}{$\mathrm{pH}$} & 0 & 5.69 & $4.79 a$ & $4.81^{c}$ & $4.86^{\mathrm{a}}$ & $* *$ \\
\hline & 7 & 5.71 & $4.76^{\mathrm{a}}$ & $4.75^{\mathrm{d}}$ & $4.71^{\mathrm{b}}$ & \\
\hline & 14 & 5.68 & $4.55^{\mathrm{b}}$ & $5.25^{\mathrm{a}}$ & $4.71^{\mathrm{b}}$ & \\
\hline & 21 & 5.75 & $4.51^{b}$ & $4.98^{\mathrm{b}}$ & $4.65^{c}$ & \\
\hline \multirow[t]{4}{*}{ CL\% } & 0 & $26.67^{a}$ & $28.19 a$ & $28.16^{\mathrm{a}}$ & $28.17 \mathrm{a}$ & $* *$ \\
\hline & 7 & $23.63^{b}$ & $26.35^{\mathrm{ab}}$ & $28.07 \mathrm{~b}$ & $28.01^{a}$ & \\
\hline & 14 & $22.02^{c}$ & $26.53 \mathrm{ab}$ & $27.64^{c}$ & $26.49 \mathrm{~b}$ & \\
\hline & 21 & $21.63^{d}$ & $24.35^{\mathrm{b}}$ & $25.71^{d}$ & $24.12^{c}$ & \\
\hline
\end{tabular}

$\mathrm{T}_{1}=0 \%$ salt; $\mathrm{T}_{2}=1.5 \%$ salt concentration; $\mathrm{T}_{3}=3 \%$ salt concentration and $\mathrm{T}_{4}=5 \%$ salt concentration; $\mathrm{CL}$ = Cooking loss; NS = Non significant; Mean with different superscripts within same column differ significantly. Significant at $1 \%$ level $(\mathrm{P}<0.01)$ 
Table 5. Interaction effect of proximate composition, $\mathrm{pH}$ and cooking loss (CL) of fresh and frozen nugget on storage time

\begin{tabular}{|c|c|c|c|c|c|c|}
\hline \multirow[t]{2}{*}{ Parameters } & \multirow{2}{*}{$\begin{array}{l}\text { Storage time } \\
\text { (Days) }\end{array}$} & \multicolumn{4}{|c|}{ Treatment } & \multirow[t]{2}{*}{ Sig. Level } \\
\hline & & $\mathrm{T}_{1}$ & $\mathrm{~T}_{2}$ & $\mathrm{~T}_{3}$ & $\mathrm{~T}_{4}$ & \\
\hline \multirow{5}{*}{$\begin{array}{l}\text { DM\% on } \\
\text { storage time }\end{array}$} & 0 & $30.59 \mathrm{~b}$ & 30.65 & 31.02 & 32.61 & $* *$ \\
\hline & 15 & $31.09 \mathrm{ab}$ & 30.94 & 31.70 & 32.87 & \\
\hline & 30 & $31.29 \mathrm{ab}$ & 31.02 & 31.27 & 32.73 & \\
\hline & 45 & $31.14^{\mathrm{ab}}$ & 30.43 & 31.59 & 32.74 & \\
\hline & 60 & $31.64^{\mathrm{a}}$ & 31.17 & 32.09 & 33.24 & \\
\hline \multirow[t]{5}{*}{ Ash\% } & 0 & $1.17 \mathrm{~b}$ & $1.13^{\mathrm{d}}$ & $1.08^{c}$ & $1.06^{\mathrm{b}}$ & $* *$ \\
\hline & 15 & $1.26^{\mathrm{ab}}$ & $1.24^{\mathrm{b}}$ & $1.18^{a}$ & $1.14^{\mathrm{a}}$ & \\
\hline & 30 & $1.28^{\mathrm{ab}}$ & $1.21^{\mathrm{c}}$ & $1.19^{a}$ & $1.17^{a}$ & \\
\hline & 45 & $1.27 \mathrm{ab}$ & $1.25^{\mathrm{b}}$ & $1.13 \mathrm{~b}$ & $1.14^{\mathrm{a}}$ & \\
\hline & 60 & $1.32^{\mathrm{a}}$ & $1.30^{\mathrm{a}}$ & $1.15^{\mathrm{ab}}$ & $1.19^{a}$ & \\
\hline \multirow[t]{5}{*}{$\mathrm{CP} \%$} & 0 & $22.31^{a}$ & $21.63^{a}$ & $21.48 \mathrm{bc}$ & $21.44^{\mathrm{a}}$ & ** \\
\hline & 15 & $20.22^{b c}$ & $20.90^{b}$ & $19.84^{\mathrm{d}}$ & $20.07 \mathrm{~b}$ & \\
\hline & 30 & $20.45^{b}$ & $20.71^{b c}$ & $20.22^{c}$ & $20.05^{b}$ & \\
\hline & 45 & $19.73^{\mathrm{cd}}$ & $20.55^{c}$ & $22.93^{a}$ & $19.94^{c}$ & \\
\hline & 60 & $19.33^{d}$ & $20.15^{d}$ & $22.53^{a b}$ & $19.51^{\mathrm{d}}$ & \\
\hline \multirow[t]{5}{*}{ Fat $\%$} & 0 & 6.85 & $7.64^{\mathrm{a}}$ & $7.74^{\mathrm{a}}$ & $7.75^{a}$ & $* *$ \\
\hline & 15 & 7.23 & $7.24^{\mathrm{ab}}$ & $7.18^{\mathrm{ab}}$ & $7.09 \mathrm{~b}$ & \\
\hline & 30 & 7.22 & $7.13^{\mathrm{b}}$ & 7.19ab & $7.17 \mathrm{~b}$ & \\
\hline & 45 & 7.20 & $7.27 \mathrm{ab}$ & $7.14^{\mathrm{ab}}$ & $7.09 \mathrm{~b}$ & \\
\hline & 60 & 6.90 & $6.97 \mathrm{c}$ & $6.84^{b}$ & $6.79 c$ & \\
\hline \multirow[t]{5}{*}{$\mathrm{pH}$} & 0 & $5.69^{a}$ & $5.71^{\mathrm{a}}$ & $5.68^{\mathrm{a}}$ & $5.75^{\mathrm{a}}$ & $* *$ \\
\hline & 15 & $5.68^{a}$ & $4.98^{\mathrm{b}}$ & $4.76^{c}$ & $4.72^{c}$ & \\
\hline & 30 & $4.74^{b}$ & $4.93^{b}$ & $4.89 c$ & $4.87 \mathrm{c}$ & \\
\hline & 45 & $4.70^{\mathrm{b}}$ & $4.97 \mathrm{~b}$ & $5.47 \mathrm{ab}$ & $5.19 \mathrm{~b}$ & \\
\hline & 60 & $4.25^{c}$ & 5.19ab & $5.30^{\mathrm{b}}$ & $5.18^{\mathrm{b}}$ & \\
\hline \multirow[t]{5}{*}{ CL\% } & 0 & $26.67 \mathrm{c}$ & $23.63^{d}$ & $22.02^{\mathrm{d}}$ & $21.63^{d}$ & $* *$ \\
\hline & 15 & $30.19 \mathrm{~b}$ & $28.35^{c}$ & $28.53^{c}$ & $26.35^{c}$ & \\
\hline & 30 & $30.17 b$ & $30.03 \mathrm{~b}$ & $28.49 c$ & $26.12^{\mathrm{cd}}$ & \\
\hline & 45 & $30.16^{b}$ & $30.06^{b}$ & $29.64^{b}$ & $27.71^{b}$ & \\
\hline & 60 & $31.16^{\mathrm{a}}$ & $31.06^{\mathrm{a}}$ & $30.64^{a}$ & $28.71^{\mathrm{a}}$ & \\
\hline
\end{tabular}

$\mathrm{T}_{1}=0 \%$ salt; $\mathrm{T}_{2}=1.5 \%$ salt concentration; $\mathrm{T}_{3}=3 \%$ salt concentration and $\mathrm{T}_{4}=5 \%$ salt concentration; $\mathrm{CL}$ = Cooking loss; NS = Non significant; Mean with different superscripts within same column differ significantly. Significant at $1 \%$ level $(\mathrm{P}<0.01)$ 


\section{REFERENCES}

AOAC. 1995. Official methods of analysis, $16^{\text {th }}$ ed. Washington: Association Official Analytical Chemistry.

Angulo, A. M. and Gil, J. M. 2007. Risk perception and consumer willingness to pay for certified beef in Spain. Food Quality and Preference, 18(8): 1106-1117.

Aggett, P. J., Antoine, J. M., Asp, N. G., Bellisle, F., Contor, L., Cummings, J. H. 2005. Process for the assessment of scientific support for claims on foods.Consensus on criteria. European Journal of Nutrition, 44(1): 1-31.

Chantrapornchai, W. and McClements, D. J. 2002. Influence of $\mathrm{NaCl}$ on optical properties, large-strain rheology and water holding capacity of heat-induced whey protein isolate gels. Food Hydrocolloids, 16: 467-476.

Dahl, L. K. 1972. Salt and hypertension. American Journal of Clinical Nutrition, 25: 231-244.

DLS, 2009. Directorate of Livestock Services, Government of the Peoples' Republic of Bangladesh.

Durack, E., Alonso-Gomez, M. and Wilkinson, M. G. 2008. Salt: a review of its role in food science and public health. Current Nutrition \& Food Science, 4: 290-297.

Foegeding, E. A. and Lanier, T. C. 1987. The contribution of nonmuscle proteins to texture of gelled muscle protein foods. Cereal Foods World, 32: 202-205.

Fonseca, M. C. and Salay, E. 2008. Beef, chicken and pork consumption and consumer safety and nutritional concerns in the city of Campinas, Brazil. Food Control, 19(11): 1051-1058.

Fennema, O. R. 1975. Introduction to food preservation. In: principles of foodscience. (Ed. O. R. Fennema). Marcel Dekker, Inc. New York. pp. 1-7.

Law, N., Frost, C. and Wald, N. 1991a. By how much does dietary salt reduction lower blood pressure; I-analysis of observational data among populations. British Medical Journal, 302: 811-815.

Law, N., Frost, C. and Wald, N. 1991b. By how much does dietary salt reduction lower blood pressure; I-analysis of observational data among populations. British Medical Journal, 302: 819-824.

Ismed Lukman, Nurul Huda and Noryati Ismail. 2009. Physicochemical and sensory properties of commercial chicken Nuggets. As. J. Food Ag-Ind. 2: 171-180.

Tobin, B., O'Sullivan, M. G., Hamill, R. and Kerry, J. P. 2012a. Effect of varying salt and fat levels on the sensory quality of beef patties. Meat Science, 91: 460-465.

Tobin, B., O'Sullivan, M. G., Hamill, R. and Kerry, J. P. 2012b. Effect of varying salt and fat levels on the sensory and physiochemical quality of frankfurters. Meat Science (Submitted).

Rahman, M. M. 1992. Mangser Swasthyabidha (1st Ed.), Bangla Academy, Dhaka, pp. 8.

World Health Organization. 2009. Cardiovascular Diseases.http://www.who.int/ mediacentre/ factsheets/fs317/en/index.html;http://www.who.int/cardiovascular_diseases/priorities/en/i ndex.html. 